\title{
ABILITY OF PLANT-DERIVED OILS TO INHIBIT DAMPWOOD TERMITE (Zootermopsis augusticollis) ACTIVITY
}

\author{
Rushda Fatima ${ }^{1}$, Jeffrey J. Morrell ${ }^{2, \wedge}$
}

\begin{abstract}
The potential effects of plant derived oils on survival of dampwood termite (Zootermopsis augusticollis) workers was explored on western white pine sapwood blocks. All of the oils rapidly affected protozoa in the hindgut of termite workers and protozoa loss was closely followed by worker mortality. The effects were most rapid with wood treated with Neem, Eucalyptus or Jatropha oils, but mortality also occurred within 7 days with workers exposed to blocks treated with Jojoba or linseed oil. The results illustrate the relatively high sensitivity of dampwood termites to these types of treatment and suggest the potential for natural product control of this termite species.
\end{abstract}

Keywords: Dampwood termites, Eucalyptus oil, Jatropha oil, jojoba oil, linseed oil, neem, plant oils, protozoa.

\section{INTRODUCTION}

Dampwood termites (Zootermopsis augusticollis) are found throughout the western slopes of the Pacific Northwest where they are important degraders of downed woody debris (Castle 1934, Furniss and Carolin 1977). Although they are primarily forest dwellers, they sometimes invade structures and become locally important (Mankoswki and Morrell 2000). While dampwood termites are relatively sensitive to most traditional wood preservatives (Mankowski and Morrell 1993), there is also considerable interest in evaluating nontraditional methods of insect protection. Among these systems are oils derived from foliage, seeds, wood or bark of many plants. A variety of plant-derived oils have been explored for protecting wood against fungi and insects, but there are no reports concerning activity of these materials against dampwood termites.

There are a wide array of possible plant-derived oil candidates including linseed oil, Jatropha oil, eucalyptus oil, neem oil, and cashew nut shell oil.

Linseed oil is used in products such as resins, inks, soaps, varnishes, wood treatments and the pharmaceutical industry due to the ease of drying, ready availability and high boiling point at atmospheric pressure (Chemwatch 2007). Linseed oil was also an important component in the pentachlorophenol solution recommended by the U.S. Forest Products Laboratory for external preservative treatment. Jatropha curcas nut oil has been shown to be effective against the Philippine milk termite Coptotermes vastator (Isoptera: Rhinotermitidae) and the Formosan termite (Coptotermes formosanus) (Singh and Soshilkumar 2008, Acda 2009). Eucalyptus oil has also been shown to be highly repellent against termites (Manzoor et al. 2012).

Neem oil has been widely studied and is used as an insect repellent, feeding inhibitor, growth retardant, and sterilant (Chavan and Nikam 1988, Dhyani and Tripathi 2006, Grace and Yates 1992, Machado et al. 2013). Cashew nut shell liquid is phenolic and can be used to protect timber and textiles against insect and fungal attack (Cornelius 1996).

\footnotetext{
' University of Agriculture, Faisalabad, Pakistan.

${ }^{2}$ Department of Wood Science \& Engineering, Oregon State University, Oregon, USA.

^Corresponding Author: jeff.morrell@oregonstate.edu

Received: 12.09.2014 Accepted: 22.03.2015
} 
While most of these natural products have been used in other applications, there are limited reports of their activity as wood protectants against dampwood termites (Ohmura et al. 2006). In this report, we describe preliminary trials of natural product-extract-treated pine sapwood against dampwood termite workers.

\section{MATERIALS AND METHODS}

\section{Termite Collection}

Dampwood termites (Zootermopsis augusticollis Hagen) were collected from decaying Douglas-fir logs at a site north of Corvallis, Oregon. Termite workers ( $4^{\text {th }}$ to $6^{\text {th }}$ instar) were carefully removed from the logs, placed in containers containing wood from the original colony and maintained at $20-25^{\circ} \mathrm{C}$ until needed. Termites were used within 2 weeks of collection.

\section{Wood Preparation and Treatment}

Western white pine (Pinus monticola L.) blocks (10 by 20 by $60 \mathrm{~mm}$ long) were cut from defect-free sapwood boards $\left(224\right.$ blocks total). The blocks were oven-dried $\left(50^{\circ} \mathrm{C}\right)$ and weighed before being allocated to 30 groups of 7 blocks each. The remaining blocks were used as controls. These blocks were then immersed in a solution of one of 5 oils at concentrations of 0,$5 ; 1 ; 3 ; 5$; or $10 \%(\mathrm{wt} / \mathrm{wt})$ diluted in ethanol (Table 1). The solutions were subjected to a $1 \mathrm{hr}$ vacuum $(80 \mathrm{kPa})$ followed by a 2 hour pressure period $(700 \mathrm{kPa})$. The pressure was released, the blocks were removed from the treatment solution, blotted dry and weighed to determine net solution absorption. The blocks were then dried at $50{ }^{\circ} \mathrm{C}$ and weighed. Control blocks were treated with $95 \%$ ethanol alone and similarly oven dried and weighed.

Table 1. Characteristics of selected plant-derived oils evaluated against dampwood termites.

\begin{tabular}{|c|c|c|c|}
\hline Trade name & Plant Source (and part) & Concentration & Source \\
\hline Jatropha & Jatropha curcas Linn (seeds) & $100 \%$ & $\begin{array}{c}\text { SGB Biofuels, San } \\
\text { Diego, CA }\end{array}$ \\
\hline Linseed oil & Lignum usitatissimum (seeds) & $100 \%$ & Sigma Aldrich \\
\hline Eucalyptus oil & $\begin{array}{r}\text { Eucalyptus camaldulensis Dehr } \\
\text { (foliage) }\end{array}$ & $70-75 \%$ & Sigma Aldrich \\
\hline Neem oil & $\begin{array}{r}\text { Azadirachta } \text { indica A. Juss. } \\
\text { (foliage) }\end{array}$ & $100 \%$ & $\begin{array}{c}\text { Garden Essential, } \\
\text { Riverside, CA }\end{array}$ \\
\hline Jojoba oil & $\begin{array}{r}\text { Simmondsia chinensis (Link.) } \\
\text { C.K.Schneid. (seeds) }\end{array}$ & $100 \%$ & Sigma Aldrich \\
\hline
\end{tabular}




\section{Termite Exposures}

The blocks were exposed to termites in $115 \mathrm{~mm}$ diameter Petri dishes. Briefly, $3 \mathrm{~g}$ of vermiculite and $6 \mathrm{~g}$ of distilled water were added to a petri dish along with 15 workers and one test block. Each oil/concentration was replicated on 7 blocks. The blocks were incubated with termites for 24 days at $23{ }^{\circ} \mathrm{C}$ on a laboratory bench. The plates were incubated in the same area and we believe there was some movement of vapors between plates. The number of live termites was assessed every 3 to 4 days and dead workers were removed. A single live termite was removed from each plate after 1,2, or 3 weeks. The hindgut was removed from each worker, placed into $50 \mathrm{ul}$ of a $9 \%$ saline solution and agitated for 45-60 seconds (Mankowski and Morrell 1993, Maudlin et al. 1981). Protozoa can serve as an early indicator of termite health (Doolittle et al. 2007). A subsample of the resulting mixture (3-5 ul) was removed, placed on a haemocytometer slide and the number of viable protozoa (Trichonympha spp. and Trichomitopsis spp.) were counted. The tests were concluded after 24 days when all termites had succumbed.

At the end of the incubation period, the blocks were removed from their chambers, oven dried $\left(50{ }^{\circ} \mathrm{C}\right)$ and weighed to determine mass loss.

\section{RESULTS AND DISCUSSION}

Termite mortality tended to be elevated in all chambers, possibly as a result of residual ethanol in the blocks. The $50{ }^{\circ} \mathrm{C}$ oven drying procedure was intended to eliminate residual ethanol, but mortality steadily increased over the 24 day incubation period in chambers with the control blocks. However, mortality in chambers containing the oil treated blocks increased much more rapidly than the controls, allowing for some assessment of treatment efficacy.

Mortality after 4 days of exposure tended to increase with increased treatment level for all of the oils tested, although there were some inconsistencies (Table 2). Mortality increased markedly at all treatment levels after 7 days and there were few differences between the treatments. Mortality was nearly complete after 2 weeks of exposure, indicating that all of the extracts were lethal to the workers. One difficulty with this assessment method was the volatility of the oils, which tended to create near fumigation conditions in the chambers. While establishing more rapid air exchange might have reduced this problem, it would have resulted in potential desiccation of the workers. Volatility would also be a problem if these extracts were used commercially since they would eventually dissipate to the point where they were not longer present at effective levels. They might also have potential negative effects on inhabitants of structures treated with these materials. 
Table 2. Effects of exposure of dampwood termite workers to western white pine sapwood blocks treated with selected natural oils as measured by termite mortality and wood mass loss.

\begin{tabular}{|c|c|c|c|c|c|c|}
\hline \multirow{2}{*}{ Treatment } & \multirow{2}{*}{$\begin{array}{c}\text { Conc. } \\
(\%)\end{array}$} & \multicolumn{4}{|c|}{ Termite mortality $(\%)^{\mathrm{a}}$} & \multirow{2}{*}{$\begin{array}{c}\text { Mass Loss } \\
(\%)^{\mathrm{b}}\end{array}$} \\
\hline & & 4 days & 7 days & 10 days & 14 days & \\
\hline None & - & 9 & 14 & 29 & 52 & 15,3 \\
\hline \multirow{6}{*}{ Eucalyptus oil } & 0,5 & 30 & 78 & 92 & 100 & 5,1 \\
\hline & 1 & 47 & 80 & 88 & 100 & 5 \\
\hline & 3 & 58 & 77 & 92 & 100 & 5,8 \\
\hline & 5 & 4 & 18 & 57 & 90 & 6,4 \\
\hline & 10 & 45 & 82 & 96 & 100 & 8,3 \\
\hline & 15 & 82 & 95 & 100 & 100 & 10,7 \\
\hline \multirow{6}{*}{ Jojoba oil } & 0,5 & 52 & 73 & 87 & 100 & 6,5 \\
\hline & 1 & 42 & 76 & 91 & 100 & 7,7 \\
\hline & 3 & 53 & 78 & 88 & 100 & 7,7 \\
\hline & 5 & 10 & 17 & 55 & 68 & 4,6 \\
\hline & 10 & 90 & 95 & 100 & 100 & 5 \\
\hline & 15 & 93 & 96 & 99 & 100 & 5 \\
\hline \multirow{6}{*}{ Jatropha } & 0,5 & 55 & 80 & 93 & 100 & 8,2 \\
\hline & 1 & 47 & 75 & 90 & 100 & 4,9 \\
\hline & 3 & 35 & 77 & 90 & 100 & 5,5 \\
\hline & 5 & 78 & 85 & 92 & 99 & 5 \\
\hline & 10 & 65 & 80 & 100 & 100 & 4,5 \\
\hline & 15 & 12 & 87 & 100 & 100 & 5 \\
\hline \multirow{6}{*}{ Neem } & 0,5 & 48 & 80 & 91 & 100 & 5,7 \\
\hline & 1 & 44 & 73 & 89 & 100 & 4,7 \\
\hline & 3 & 53 & 78 & 92 & 100 & 4,2 \\
\hline & 5 & 23 & 71 & 100 & 100 & 4,4 \\
\hline & 10 & 71 & 86 & 100 & 100 & 4,8 \\
\hline & 15 & 67 & 93 & 100 & 100 & 3,8 \\
\hline \multirow{6}{*}{ Linseed oil } & 0,5 & 30 & 68 & 90 & 100 & 4,6 \\
\hline & 1 & 53 & 82 & 92 & 100 & 4,1 \\
\hline & 3 & 62 & 83 & 95 & 100 & 4,3 \\
\hline & 5 & 37 & 73 & 91 & 100 & 4,4 \\
\hline & 10 & 29 & 78 & 96 & 100 & 4,2 \\
\hline & 15 & 53 & 64 & 98 & 100 & 3,1 \\
\hline
\end{tabular}

${ }^{a}$ Values represent means of mortality of 15 workers in each of 7 petri dishes

${ }^{b}$ Values represent means of 7 blocks per treatment oil/concentration level. 
Mass losses of blocks exposed to termite attack ranged from 3,6 to 15,3\% (Table 2). The vast majority of blocks lost between 3 and $6 \%$ mass, but exhibited little evidence of termite attack. The exceptions were the control blocks which experienced 15,3\% mass loss. Mass losses on the blocks treated with the various oils were believed to reflect volatilization of the oils from the blocks rather than wood loss and this was supported by the lack of visible termite attack. Volatility would be an important quality of these oils. Excess volatility would result in rapid depletion of the oil from the wood, allowing termites to attack the wood. However, some volatility would be beneficial because it would likely create a feeding deterrent near the wood.

Protozoa frequency measurements provided an indirect measure of termite health. Protozoa are critical for nutrition of lower termites and workers with declining protozoa frequencies are generally in declining health. Thus, protozoa assessments can provide an early measure of toxicant effect.

Protozoa levels in control blocks tended to decline over the 3 week evaluation period $(226,119$, and 56 Trichonympha spp at 1,2, and 3 weeks, respectively; 104, 67, and 38 Trichomitopsis at the same intervals), suggesting that removal from the colony had an overall negative effect on termite health (Table 3 ). Levels of Trichonympha were over twice those of Trichomitopsis at the 7 day sampling and frequency of both species declined at proportional levels over the next two weeks. Both protozoa genera were still present, albeit at lower frequencies in the hindgut after 3 weeks of exposure to the control blocks. Both protozoa genera were absent from the guts of workers exposed to Neem, Eucalyptus or Jatropha oils at the one week sampling, indicating that these oils had a profound and nearly immediate negative effect on termite health. These effects were also illustrated by the rapid mortality observed in plates containing blocks treated with these oils. Protozoa levels in workers exposed to blocks treated with $0,5 \%$ jojoba oil were similar those observed in the control blocks at the one week point, but then declined with increasing oil concentration. Protozoa were absent in the hindguts of workers exposed to blocks treated with 3,10 or $15 \%$ jojoba oil, but present at modest levels in workers exposed to blocks treated with $5 \%$ oil. The reasons for the presence of viable protozoa at the $5 \%$ treatment are unclear. Protozoa were present at much reduced levels in workers exposed to blocks treated with $0,5 \%$ linseed oil and then were absent from workers exposed to blocks treated with higher concentrations of this oil. The protozoa results illustrate the profound effect of the various oils on protozoa survival and the subsequent effect of protozoa loss on worker survival.

Table 3. Effect of a 7 day exposure of dampwood termite workers to increasing concentrations of essential oils on frequency of two protozoa genera in the hindgut. ${ }^{\mathrm{a}}$

\begin{tabular}{|l|l|l|l|l|l|l|}
\hline \multirow{2}{*}{ Essential oil } & \multirow{2}{*}{ Protozoa } & \multicolumn{5}{|l|}{ Protozoa Frequency By Concentration } \\
\cline { 3 - 8 } & & $0,5 \%$ & $1 \%$ & $3 \%$ & $5 \%$ & $10 \%$ \\
\hline Jojoba & Trichonympha spp. & 186 & 93 & 0 & 67 & 0 \\
\hline & Trichomitopsis spp. & 86 & 44 & 0 & 36 & 0 \\
\hline Linseed oil & Trichonympha spp. & 67 & 0 & 0 & 0 & 0 \\
\hline & Trichomitopsis spp. & 34 & 0 & 0 & 0 & 0 \\
\hline
\end{tabular}

${ }^{\mathrm{a}}$ Trichonympha and Trichomitopsis spp. frequencies were 226 and 104, respectively, on nontreated controls

\section{CONCLUSIONS}

All of the essential oils rapidly depleted protozoa from the hindgut of dampwood termite workers, leading to complete worker mortality within 2 weeks of exposure. The results illustrate the potential for controlling this species with natural products although the long term effects of these volatile compounds remains unclear. 


\section{ACKNOWLEDGEMENT}

The Senior author gratefully acknowledges the support of the Higher Education Commission of Pakistan that allowed her to complete this research.

\section{REFERENCES}

Acda, M.N.2009. Toxicity, tunneling and feeding behavior of the termite, Coptotermes vastator, in sand treated with oil of the physic nut, Jatropha curcas. Journal of Insect Science 9:64.

Castle, G.B. 1934. The damp-wood termites of Western United States, Genus Zootermopsis. In: Termites and Termite Control (C.A. Kofoid, Ed.). University of California Press, Berkeley, CA. pp 264-287.

Chavan, S.R.; Nikam, S.K. 1988. Investigation of alkanes from alkanes from Neem leaves and their mosquito larvicidal activity. Pesticides 22 (7): 32-33.

Chemwatch, 2007. Chemwatch Material Safety Data Sheet: Linseed Oil. Chemwatch 10701.

Cornelius, J.A.,1996. Cashew nut shell liquid and related material. Tropical Science (U.K.) 8 (2): 79-84.

Doolittle, M.; Raina, A.; Laxand, A.; Boopathy, R. 2007. Effect of natural products on gut endosymbiotic microbes in Formosan subterranean termites. International Biodeterioration Biodegradation 59:69-71.

Dhyani, S; Tripathi, S. 2006. Protection of hard and softwood through Neem leaves extracts and oil: a direction towards development of eco-friendly wood preservatives. International Research Group on Wood Protection Document No IRG/WP/06-30394. Stockholm, Sweden.

Furniss, R.L.; Carolin, V.M. 1977. Western forest insects. Miscellaneous Publication 1339, USDA Forest Service, Washington, D.C. $654 \mathrm{p}$.

Grace, J.K.; Yates, J.R. 1992. Behavioral effects of a neem insecticide on Coptotermes formosanus (Isoperta: Rhinotermitidae). Tropical Pest Management 39:176-180.

Machado, G.O.; Cookson, L.J.; Cristoforo, A.L.; Polito, W.L.; daSilva, M.R.; Junior, C.C.; Lahr, F.A.R. 2013. Wood preservation based upon neem oil: Evaluation of fungicidal and termiticidal effectiveness. Forest Products Journal 63:202-206.

Mankowski, M.E.; Morrell, J.J. 1993. Resistance of dampwood termites to preservative-treated wood. Forest Products Journal 43(9):58-60

Mankowski, M.E.; Morrell, J.J. 2000. Incidence of wood-destroying organisms in Oregon residential structures. Forest Products Journal 50(1):49-52.

Manzoor F.; Malik, S.A.; Naz, N.; Cheema, K.J.; Naz, S. 2012. Potential of antitermitic activities of eucalyptus oil. Pak J Zool 44(2): 335-339.

Maudlin, J.K.; Carter, F.L.; Rich, N.M. 1981. Protozoa populations of Reticulotermes flavipes (Kollar) exposed to heartwood blocks of 21 American species. Material und Organismen 16:15-28.

Ohmura, W.; Ozaiki, M.; Yamaoka, R. 2006. Behavioral and electrophysiological investigation on test response of the termite Zootermopsis nevadensis to wood extractives. J Wood Science 52:261-264.

Singh, N.; Sushilkumar, A. 2008. Anti-termite activity of Jatropha curcas Linn. biochemicals. Journal of Applied Sciences and Environmental Management 12(3): 67-69. 